\title{
A contribution to improved flood magnitude estimation in base of palaeoflood record and climatic implications - Guadiana River (Iberian Peninsula)
}

\author{
J. A. Ortega and G. Garzón \\ Facultad de Geología, Universidad Complutense de Madrid, Madrid, Spain
}

Received: 4 August 2008 - Revised: 22 December 2008 - Accepted: 9 January 2009 - Published: 26 February 2009

\begin{abstract}
The Guadiana River has a significant record of historical floods, but the systematic data record is only 59 years. From layers left by ancient floods we know about we can add new data to the record, and we can estimate maximum discharges of other floods only known by the moment of occurrence and by the damages caused. A hydraulic model has been performed in the area of Pulo de Lobo and calibrated by means of the rating curve of Pulo do Lobo Station. The palaeofloods have been dated by means of ${ }^{14} \mathrm{C} y{ }^{137} \mathrm{Cs}$. As non-systematic information has been used in order to calculate distribution functions, the quantiles have changed with respect to the same function when using systematic information. The results show a variation in the curves that can be blamed on the human transformations responsible for changing the hydrologic conditions as well as on the latest climate changes. High magnitude floods are related to cold periods, especially at transitional moments of change from cold to warm periods. This tendency has changed from the last medium-high magnitude flood, which took place in a systematic period. Both reasons seem to justify a change in the frequency curves indicating a recent decrease in the return period of big floods over $8000 \mathrm{~m}^{3} \mathrm{~s}^{-1}$. The palaeofloods indicate a bigger return period for the same water level discharge thus showing the river basin reference values in its natural condition previous to the transformation of the basin caused by anthropic action.
\end{abstract}

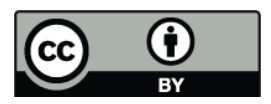

Correspondence to: J. A. Ortega (jaortega@geo.ucm.es)

\section{Introduction}

Floods cause more losses in the Iberian Peninsula than any other geological process. An assessment of risks has estimated that natural hazards in Spain have caused $1.384 €$ million losses in 10 years to the official assurance company, out of which $1.181 €$ million (85\%) correspond to floods (Ferrer et al., 2004). Large investments in watercourse regulation and canalization works have generated a false sense of security and intensive development of floodplains and the result has been an increase in the severity of damage caused by overflows. This situation is due in part to the lack of rigorous studies of floodprone areas and flood return periods. Despite the large number of historical flood records in the Iberian Peninsula, the lack of continuity and of quantifiable references make realistic determinations difficult, due to the fact that data furnished by existing records are insufficient for reliable hydrological reconstructions. As a result, the existing cartography for floodable areas is based almost entirely on records of gauge stations and processing of such data by statistical techniques and extrapolation. Palaeohydrology combines a variety of disciplines with a multidisciplinar approach, including geomorphological, hydraulical, and stratigraphical analysis. The main objective is the study of the old floods most of which have never been registered or catalogued. This way we are able to know when they occurred and also, with the use of appropriate hydraulic modeling techniques, we could know the maximum peak discharge related to the deposit. The historical record of extreme floods can range from hundreds of years, in the case of the Guadiana basin from 500 years, to thousands of years with palaeoflood information (Baker et al., 1988). In order to understand longterm fluvial records, a key challenge (Thorndycraft and Benito, 2006) is to determine periods of regionally important

Published by Copernicus Publications on behalf of the European Geosciences Union. 
river activity. In these sense Mackling and Lewin (2003) have studied periods of increased fluvial activity related to Holocene climate change. Thorndycraft and Benito (2006) establish the Holocene fluvial chronology of Spain in basis to evidence from a radiocarbon database. The palaeoflood hydrology also provides useful information in risk assessment, and especially related to climatic change, as Jarret (1989) suggest. To determine the correct magnitude of events is another goal of this studies. This aspect was suggested by Ely and Baker (1985), who stated that flood frequency analysis forms a key element in the adequate floodplain management and design of structures along a river. Current statistical methods of estimating flood frequencies often have a problem with short gaged records on the river. Slackwater deposits preserve sedimentary evidence of individual flood events and may furnish evidence of changing flood magnitude and frequency in the Holocene (Ely et al., 1993).

In Spain early studies developed by Benito et al. (1998) in the Tagus river give the first data about palaeofloods, followed later by a preliminary work by Ortega and Garzón (2003) in the Guadiana river, Thorndycraft et al. (2004) in the Llobregat river and Rico (2004) in the Segre river. Works that originally developed into aspects such as palaeoflood hydrology or climate change (Benito et al., 1996), continued with subjects like palaeoflood sedimentology (Benito et al., 2003a), magnitude and frequency (Benito et al., 2003b) or specifically about datings (Thorndycraft et al., 2003). Some preliminary works have been done in the Guadiana basin, like that of Ortega and Garzón (2003) and later by Ortega (2007), who studies recent and old floods through paleohydrologic techniques, historical floods and a gaged series of data. Other works like the one by Trigo et al. (2004) show the relationship between climatic models, like the North Atlantic Oscillation (NAO) and precipitation in the Guadiana basin, and Ortega and Garzón (2004) with NAO and floods.

The objective of this paper is: (1) to compile as much data as possible starting from systematic and historical information in order to complete the Guadiana basin flood record by using paleohydrologic information, (2) to improve the calibration of hydraulic models by using paleostage indicators and an adequate roughness assignment, (3) to increase the knowledge of the basin with all these data, improve and calculate new distribution functions and therefore adequate the quantile values and the floods magnitude and finally, (4) to give a preliminary view of the modifications in the occurrence of high magnitude floods in the basin probably related to recent climatic changes.

\section{Site description}

The Guadiana river basin is located in the SW of the Iberian Peninsula and and the river itself flows into the Atlantic Ocean (Fig. 1). The basin has $68000 \mathrm{~km}^{2}$ and is currently regulated by a hundred dams of bigger size (more than $1 \mathrm{hm}^{3}$ ). About five of these accumulate around $7000 \mathrm{hm}^{3}$ out of $11000 \mathrm{hm}^{3}$ of total dam storage, not to mention about another 200 dams with lower capacity. The average rainfall of the basin is about $550 \mathrm{~mm} /$ year and the annual evapotranspiration is about $1000 \mathrm{~mm}$. The basin can be divided into three areas: the upper one, an extensive plain based on carbonates where the Guadiana river is poorly geomorphologically defined, due to infiltration; the medium one, which crosses a paleozoic range and enters the tertiary basin of Extremadura, where the mean discharge and morphological features increase (and thus dam storage); and the lower one, where the river flows into the rocks, developing into a bedrock river. The course of the Guadiana River runs through deep gorges in the Hercynian Massifs, we established a search for palaeoflood deposits in these areas. Various sites were located, although these areas generally present difficulties of access and excavation. The Pulo do Lobo canyon, in the Mértola area, was chosen for its good depositional conditions, the possibilities of hydraulic modeling, and also because there is a gauge station with records going back to 1947. It is located in the lower course of the Guadiana River, where the river is enclosed by metamorphic materials forming a steepsided gorge; the valley is $400 \mathrm{~m}$ wide. The watershed of the Guadiana River at this reach is $60800 \mathrm{~km}^{2}$.

\section{Methodology}

The methodology of this work follows the basic lines of palaeofloods research, compiled by Benito and Thorndycraft (2004) in their methodological guidelines, with a fieldwork that gathers information from the deposits and the areas where these appear, making stratigraphic analysis (identification of flood palaeostage indicators, cronoestratigraphic relations among columns), analysis of sediments, compiling samples for dating (by ${ }^{14} \mathrm{Cy}{ }^{137} \mathrm{Cs}$ ) and setting all this into a geomorphologic and hydraulic context. The palaeoflood levels used for this work are the slackwater deposits (SWD) which, together with the paleostage indicators (PSI), create the basis of the method, which at the same time needs to accept certain standard assumptions described in the hydraulic model. A hydraulic model is created based on the SWDPSI by using the program HEC-RAS, which is adjusted to the model with a calibration of the rating curve of Pulo do Lobo and the flotsam levels of recent floods. As a final result of the method the maximum peak discharge of each flood event are obtained. Finally we come to conclusions in different items, which are the goals of the palaeoflood information like climatic implications, role of ancient floods, evolutions of tertiary relief, possibility of changes in hydraulic conditions (stationarity) or changes in flood magnitude. The authors propose a methodology in four steps:

\section{Definition of objectives,}




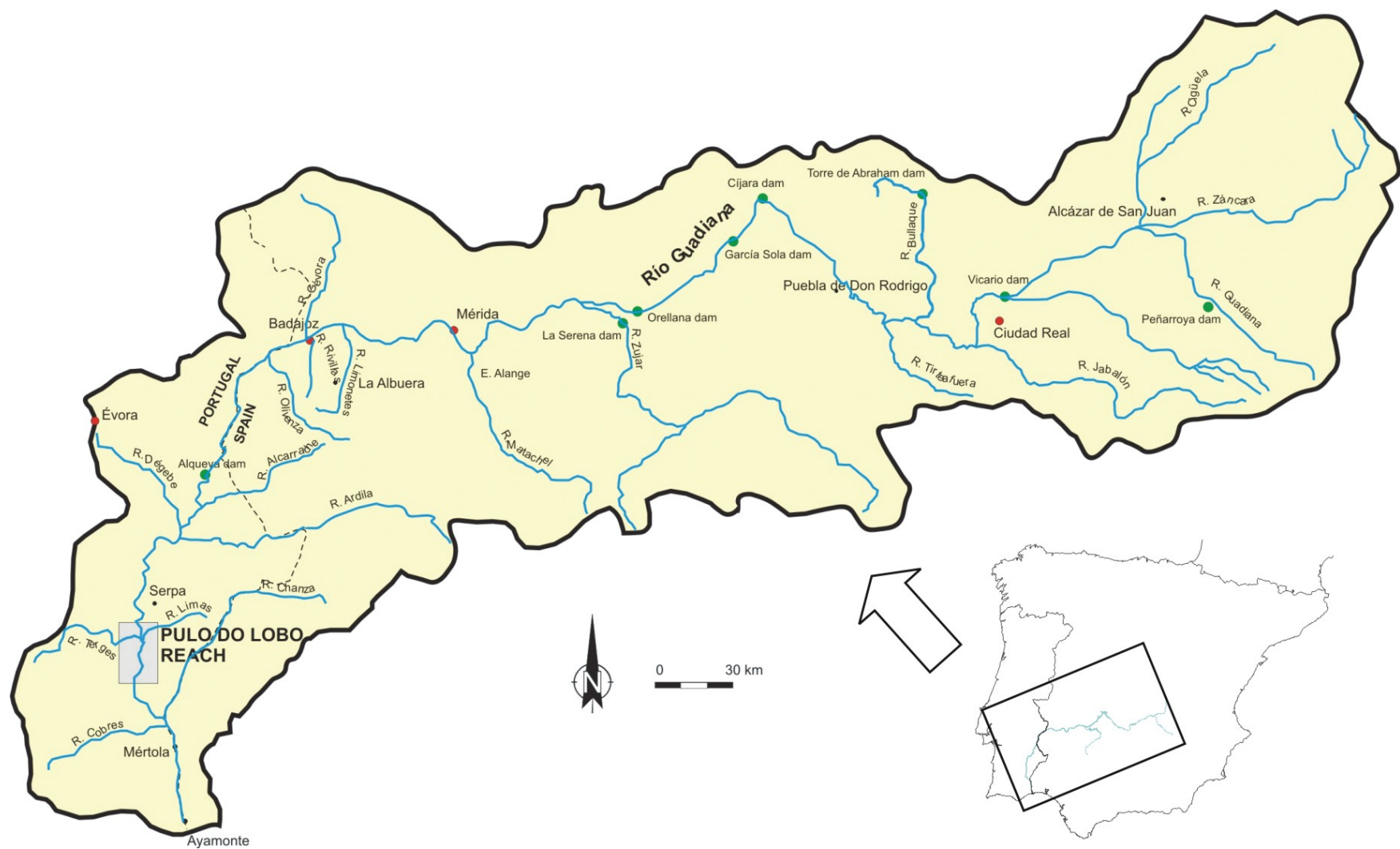

Fig. 1. Location of the study area of Pulo do Lobo within the Guadiana river basin, where the major tributaries have been indicated, as well as some of the most significant dams.

2. Description of pre-existent knowledge about Guadiana floods, like geomorphological context useful to understand slackwater deposition and hydraulic model, the Guadiana flood context with the systematic and historical record,

3. Palaeoflood studies in the Pulo do Lobo area (analysis of SWD, dating and correlation of deposits and hydraulic model and calibration),

4. Results of the study focusing on: revised flood history of the basin, the use of non-systematic data in flood magnitude and frequency and climatic significance of high magnitude floods.

Because of the complexity of the factors analysed, this paper will concentrate especially on item 3 , focusing on the results and relationships between climate and magnitude of floods.

\section{Geomorphological and historical flood context}

\subsection{Geomorphology of the reach}

From a geomorphological point of view (Fig. 2), the river reach presents special hydraulic characteristics. The Guadiana River has eroded a deep gorge in the Palaeozoic metamorphic substratum. The gorge shows a distinctive bedrock channel morphology. The valley bottom consists of a wide bedrock platform, which is incised by a deep and narrow inner channel, like the descriptions by Shepard and Schumm (1974). This single lower channel conveys all the river flow during normal phases and even low level high frequency floods. The inner channel does not appear all along the studied reach, but starts at a knickpoint formed by a $16 \mathrm{~m}$ high waterfall close to Site 3 . During large floods the flanking bedrock benches are covered by water and the inner channel is not visible.

The bedrock bench remains perched like a strath-terrace for most of the time, only covered by water during medium to high floods. Wohl (1992) describes a similar morphology for the Burdekin Gorge in Australia, and also considers that the inner channel and bedrock benches are shaped 


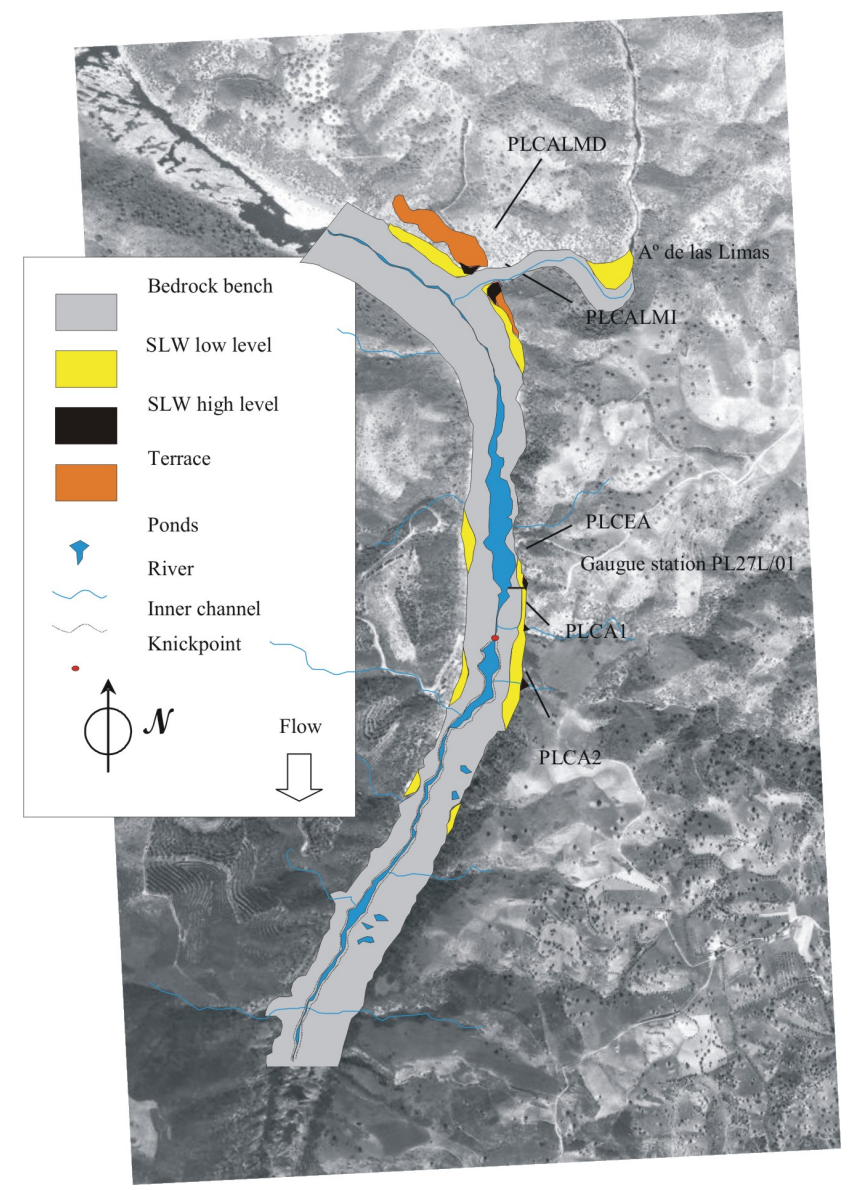

Fig. 2. Location of the slackwater deposits on different sites (Site 1PLCALMD and PLCALMI, Site 2-PLCEA, Site 3-PLCA1 and Site 4-PLCA2) and next to the main morphologic elements of a reach.

during high magnitude floods. The shape of the channel will be determined by the minimum variance in energy between reaches (Wohl et al., 1999), considering that the principles of uniform energy expenditure of alluvial channels might be also applied on bedrock channels with a relatively homogeneous substratum. However, what most influences hydraulic behaviour during high-water periods is the presence of the bedrock bench, which controls the low-medium flow dynamics under which slackwater deposits are formed.

4.2 The Guadiana floods: historical and systematic flood record

We attempted to establish a flood frequency analyses for the Guadiana River. Systematic gauge station records for the Guadiana basin, as for most of the Iberian Peninsula, begin in 1912 (only mean discharge). However, only a few stations preserve a continuous, reliable record on which to base detailed hydrological analysis, but there are no data in the study area until 1947, when the gauge station of Pulo do Lobo $(27 \mathrm{~L} / 01)$ is settled. The largest floods at this gauge station have been recorded in $1947\left(8127 \mathrm{~m}^{3} \mathrm{~s}^{-1}\right)$ and 1997 $\left(7210 \mathrm{~m}^{3} \mathrm{~s}^{-1}\right)$ and are both of medium magnitude.

In the towns of Badajoz and Mérida, as in various other riverine towns of Spain and Portugal (Mértola, Sanlucar de Guadiana, Alcoutim), there are some historical marks defining the height reached by the waters. All these marks indicate that the highest flood-level on record is that of 1876 . With an estimated discharge of $10000 \mathrm{~m}^{3} \mathrm{~s}^{-1}$ at Badajoz and approximately $11000 \mathrm{~m}^{3} \mathrm{~s}^{-1}$ at Mértola (Portugal), downstream of Pulo do Lobo, this flood has been considered for years, the major flood occurred in the Guadiana River, based on historical information.

Apart from the instrumental record and the marks of historical floods, there is a good record of historical floods in the basin going on since the 16th century, although some isolated references to floods during the 7th century also exist (like the $620 \mathrm{AD}$ event that destroyed the Cauliana monestry). The main historical events mentioned by Ortega (2007) related to the damages caused to the Roman Bridge of Badajoz date back to $1545,1596,1603,1758,1766,1796,1823,1859$ and 1876 AD. Many of them, as we will see, coincide with events registered in the SWD in Pulo do Lobo. Most of these events are related to floods in the winter months produced by Atlantic frontal systems (Ortega and Garzón, 2003).

\section{Palaeofloods studies}

\subsection{The Slackwater deposits at Pulo do Lobo reach}

It is in this canyon that the principal SWD have been located at four sites (Fig. 2): Arroyo de las Limas section (Site 1, samples CAL), gauge station section (Site 2, sample CEA), Arroyo 1 section (Site 3, samples CA1) and Arroyo 2 section (Site 4, samples CA2). All the deposits described are on the left bank of the river and form benches backing on to the valley walls in ponding and eddy bar zones. They are situated at the confluence of major tributaries like Arroyo de las Limas (Site 1) and other smaller creeks (Sites 3 and 4). Site 2 lies at the exit of a narrowing of the canyon, where the Pulo do Lobo gauge station is located.

Most of the deposits are composed of fine to very fine sand and silt. In some cases these are arranged as couplets or pairs of coarser and finer material which intercalate as the result of a single sediment pulse in zones favourable to deposition (Kochel and Baker, 1988). Both deposits correspond to the various energy phases that the flood goes through: first, a stronger impulse with rapid loss of competence and deposition of coarser material, followed by a pause during which the finer fractions left in suspension are deposited.

We analyzed deposits on slackwater benches occupying high positions and thus relatively well protected from floods with low return periods. No sedimentary structures are pre- 
sent at the high deposit locations, but these are well developed in the lower units close to the bedrock bench. The reason for the absence of structures in the upper part could be that these are zones of high velocity, or that there has been ponding of waters with scarcely any tractive energy. The flow level rises rapidly in flashfloods, which are frequent in the area. The discharge of material tends to be instantaneous and prevents the build-up of structures (Baker, 1987). In addition, the deposits are highly bioturbated by roots and organisms living in the sandy substrate, and this produces complete homogenization making it impossible to identify levels.

There is a characteristic level of lightly-compacted deposits that marks the limit between floods with low return periods and the better-preserved zone corresponding to higher return periods. It is in the lower benches that we find sedimentary structures: climbing ripples, planar cross bedding, trough cross bedding, herringbone cross bedding. In tributary mouths, pebbles as well as the larger sand grain sizes are present. In some cases the deposit thickness of a single flood is as much as one meter, the most frequent thickness being $40 \mathrm{~cm}$ or less. This scant thickness could be due to the size and openness of the valley cross-section and to the absence of terraces favoring the deposition of large volumes of material.

\subsection{Dating and correlations of deposits}

Two methods have been used to date the SWD deposits. One is ${ }^{137} \mathrm{Cs}$ used to determine whether the deposit is earlier or later than 1952 (Ely et al., 1992), the year in which the nuclear emissions of this element first began to accumulate on soil surfaces. The other and principal method is ${ }^{14} \mathrm{C}$. Analysis by the ${ }^{14} \mathrm{C}$ Standard method has shown that results are not always very satisfactory in these cases. Therefore the organic fraction (charcoal and branches) was separated from the inorganic fraction by washing and flotation. Samples were dated following the AMS procedure by BETA Lab. The results are shown in Table 1.

\subsection{Hydraulic model and calibration}

One of our main goals in this study was to determine lowfrequency flood peak discharges. These floods are not recorded at the gauge stations, which were built much more recently than the sedimentary record that we have compiled. The hydraulic model was used following the SWDPSI methodology and accepting certain standard assumptions (O'Connor and Webb, 1988; Hoggan, 1989; Baker, 1989; House and Pearthree, 1995): steady flow varies gradually and is one-dimensional; energy slope is uniform between cross sections; energy loss coefficients and cross section characteristics are representative of surveyed floods; channel cross section boundaries are stable; the PSIs approximate the stage of the floods considered; SWDs represent a mini- mum peak flood stage; flotsam represents the highest water surface; there has been negligible scour or deposition in the channel in the time since the flood peak.

The numerical model used was HEC-RAS, which considers stationary flow and step backwater conditions. The best fit was achieved by modelling recent floods whose discharges were recorded at the gauge stations and/or had deposited flotsam levels. Numerous PSIs, mainly flotsam, were mapped throughout the length of the reach and related to the recent flood of 1997 and served to verify the flow characteristics and the water surface profile at the Pulo do Lobo gauge station (Portugal, 27L/01). This is a reliable control for the model and was used to verify the base hypothesis in order to achieve the best boundary conditions. It also improves the results obtained in a first approximation by Ortega and Garzón (2003) for the same palaeoflood events. The methodology followed to calibrate from flotsam consists of assigning a liable value to each level depending on the hydraulic characteristics of each section (roughness, flow disturbances, obstacles, possible overflood of local water levels). By this method it is possible to filter mistakes in comparison PSI vs. hydraulic model.

In geomorphological terms, the entire profile is influenced by two elements: the bedrock bench and the presence of flow-confining elements, contractions and expansions. The bedrock bench decreases in height from the highest part of the profile, upstream, until it reaches a point where the level rises as a threshold, located before a narrowing of the canyon walls. During the 1997 flood (Fig. 3), the location of the various flotsam deposits followed a line parallel to this level. The situation is maintained up to a given water level height, above which the flow ceases to be influenced by this bed obstacle. To conclude, the bedrock bench influences hydraulics and deposition of medium- and low-discharge floods. Deposition parallel to the bedrock surface occurs in lower deposits, while the higher deposits present a more uniform water surface profile. Moreover, in the lower part of the reach, the inner channel downstream of the waterfall favours the creation of a hydraulic drop paralleling the bedrock bench.

Manning's n was used in the hydraulic model. According to Costa (1987), the choice of this coefficient raises problems for indirect determination of discharges. In the present case, this entailed no significant changes in the estimated flows because the wide valley reduced friction in large discharges (O'Connor and Webb, 1988). Under these circumstances, discharge variations do not normally exceed 5 to $20 \%$ of the total volume (Enzel et al., 1994; House and Peartree, 1995). The $n$ values that best reflected the real ones obtained in the rating curve of the gauge station were 0.055 in the channel and 0.06 at the margins, where the vegetation is less dense. But the value of each profile has been altered according to their characteristics (obstacles, vegetation, changes in cross section), the obtained calibration using the gauged data (Fig. 4) show a good match with higher levels $(\mathrm{Cal} 2)$ rather than with lower levels (Cal 1). The adjustment is better for 
Table 1. Results of palaeoflood dating with charcoal using ${ }^{14} \mathrm{C}$ (standard and AMS) and ${ }^{137} \mathrm{Cs}$, interpreted historical flood and peak discharge estimations of each event.

\begin{tabular}{|c|c|c|c|c|c|c|c|c|c|}
\hline $\begin{array}{l}\text { SWD sample } \\
\text { (BETA number) }\end{array}$ & Type & $\begin{array}{l}\text { Age of } \\
\text { radiocarbon }\end{array}$ & $\begin{array}{l}\text { Ratio } \\
{ }^{13} \mathrm{C} /{ }^{12} \mathrm{C}\end{array}$ & $\begin{array}{l}\text { Conventional age } \\
\text { of radiocarbon }\end{array}$ & $\begin{array}{l}\text { Calibrated age } \\
2 \sigma(\mathrm{AD})\end{array}$ & $\begin{array}{l}\text { Calibrated age } \\
1 \sigma(\mathrm{AD})\end{array}$ & $\begin{array}{l}\text { Activity } \\
\text { of }{ }^{137} \mathrm{Cs} \\
(\mathrm{pCi} / \mathrm{gr})\end{array}$ & $\begin{array}{l}\text { Interpreted } \\
\text { historical } \\
\text { flood }\end{array}$ & $\begin{array}{l}\text { Peak } \\
\text { discharge } \\
\text { estimations } \\
\left(\mathrm{m}^{3} \mathrm{~s}^{-1}\right)\end{array}$ \\
\hline $\begin{array}{l}\text { PLCALO } \\
(143410)\end{array}$ & Conv. & $270 \pm 60 \mathrm{BP}$ & $\begin{array}{l}-23.1 \\
0 / 00\end{array}$ & $300 \pm 60 \mathrm{BP}$ & $\begin{array}{l}1450-1675 \\
1775-1800 \\
1940-1945\end{array}$ & $1500-1655$ & - & $1603 \mathrm{AD}$ & 11000 \\
\hline $\begin{array}{l}\text { PLCAL1 } \\
(131869)\end{array}$ & Conv. & $\begin{array}{l}100.4 \pm 0.6 \% \\
\text { modern }\end{array}$ & $\begin{array}{l}-25.0 \\
0 / 00\end{array}$ & $\begin{array}{l}100.4 \pm 0.6 \% \\
\text { modern }\end{array}$ & Modern & Modern & $0.13 \pm 0.01$ & Modern & - \\
\hline $\begin{array}{l}\text { PLCAL3 } \\
(143411)\end{array}$ & AMS & $3230 \pm 40 \mathrm{BP}$ & $\begin{array}{l}-23.2 \\
0 / 00\end{array}$ & $3260 \pm 40 \mathrm{BP}$ & $1625-1435 \mathrm{BC}$ & $1540-1500$ ВС & 0 & $\begin{array}{l}\text { Ancient (without } \\
\text { historical record) }\end{array}$ & 10000 \\
\hline $\begin{array}{l}\text { PLCAL44 } \\
(131870)\end{array}$ & Conv. & $130 \pm 60 \mathrm{BP}$ & $\begin{array}{l}-25.0 \\
0 / 00\end{array}$ & $130 \pm 60 \mathrm{BP}$ & $1650-1955$ & $\begin{array}{l}1670-1780 \\
1795-1955\end{array}$ & - & $1758 \mathrm{AD}$ & 9000 \\
\hline $\begin{array}{l}\text { PLCAL41 } \\
(143412)\end{array}$ & AMS & $70 \pm 40 \mathrm{BP}$ & $\begin{array}{l}-23.2 \\
0 / 00\end{array}$ & $90 \pm 40 \mathrm{BP}$ & $\begin{array}{l}1675-1765 \\
1800-1940 \\
1945-1955\end{array}$ & $\begin{array}{l}1690-1730 \\
1810-1925 \\
1950-1955\end{array}$ & - & Not interpreted & - \\
\hline $\begin{array}{l}\text { PLCEA62 } \\
(131872)\end{array}$ & Conv. & $60 \pm 60 \mathrm{BP}$ & $\begin{array}{l}-25.0 \\
0 / 00\end{array}$ & $60 \pm 60 \mathrm{BP}$ & $\begin{array}{l}1675-1775 \\
1800-1940 \\
1945-1955\end{array}$ & $\begin{array}{l}1695-1725 \\
1815-1920 \\
1950-1955\end{array}$ & $0.05+0.01$ & $1947 \mathrm{AD}$ & 8127 \\
\hline $\begin{array}{l}\text { PLCA173 } \\
(131871)\end{array}$ & Conv. & $60 \pm 50 \mathrm{BP}$ & $\begin{array}{l}-25.0 \\
0 / 00\end{array}$ & $60 \pm 50 \mathrm{BP}$ & $\begin{array}{l}1680-1745 \\
1805-1935 \\
1945-1955\end{array}$ & $\begin{array}{l}1700-1720 \\
1820-1835 \\
1880-1915 \\
1950-1955\end{array}$ & - & $1947 \mathrm{AD}$ & 8127 \\
\hline $\begin{array}{l}\text { PLCA172 } \\
(143413)\end{array}$ & AMS & $280 \pm 30 \mathrm{BP}$ & $\begin{array}{l}-24.3 \\
0 / 00\end{array}$ & $290 \pm 30 \mathrm{BP}$ & $\begin{array}{l}1510-1595 \\
1615-1660\end{array}$ & $\begin{array}{l}1525-1560 \\
1630-1650\end{array}$ & - & $1545 \mathrm{AD}$ & 8000 \\
\hline $\begin{array}{l}\text { PLCA294 } \\
(140093)\end{array}$ & Conv. & $130 \pm 50 \mathrm{BP}$ & $\begin{array}{l}-25.0 \\
0 / 00\end{array}$ & $130 \pm 50 \mathrm{BP}$ & $1660-1955$ & $\begin{array}{l}1675-1775 \\
1800-1940 \\
1945-1950\end{array}$ & 0 & $1876 \mathrm{AD}$ & 10500 \\
\hline $\begin{array}{l}\text { PLCA293 } \\
(143416)\end{array}$ & AMS & $690 \pm 40 \mathrm{BP}$ & $\begin{array}{l}-24.2 \\
0 / 00\end{array}$ & $710 \pm 40 \mathrm{BP}$ & $\begin{array}{l}1255-1310 \\
1365-1380\end{array}$ & $1275-1295$ & - & $\begin{array}{l}\text { Ancient (without } \\
\text { historical record) }\end{array}$ & 10300 \\
\hline $\begin{array}{l}\text { PLCA292 } \\
(143415)\end{array}$ & AMS & $1190 \pm 40 \mathrm{BP}$ & $\begin{array}{l}-25.7 \\
0 / 00\end{array}$ & $1180 \pm 40 \mathrm{BP}$ & $765-970$ & $785-895$ & - & $\begin{array}{l}1180 \mathrm{BP} \\
\text { (probably } 680 \mathrm{AD} \text { ) }\end{array}$ & 10100 \\
\hline $\begin{array}{l}\text { PLCA291 } \\
(143414)\end{array}$ & AMS & $60 \pm 40 \mathrm{BP}$ & $\begin{array}{l}-23.2 \\
0 / 00\end{array}$ & $90 \pm 40 \mathrm{BP}$ & $\begin{array}{l}1675-1765 \\
1800-1940 \\
1945-1955\end{array}$ & $\begin{array}{l}1690-1730 \\
1810-1925 \\
1950-1955\end{array}$ & - & Not interpreted & - \\
\hline
\end{tabular}

the higher levels, which are related to medium and high magnitude events, which will be treated as models.

The contraction and expansion values used were 0.3 and 0.5 , respectively, owing to the presence of flow constrictions within the studied reach, although according to Enzel et al. (1994), this coefficient produces few significant changes in the resulting stages. A subcritical regimen was used because field studies and models with known discharges and heights had shown that the critical value was not reached in any section except for the waterfall zone in the lower part of the reach, but this only happens during maximum discharge events no higher $4000 \mathrm{~m}^{3} \mathrm{~s}^{-1}$. Over this level the waterfall and the inner channel are totally covered and the river has no flow conditions changes. The model was difficult to construct at this point, and so the last profile was discarded in order to achieve an accurate water surface profile.

These values were used to model the discharge estimations for each of the deposits described and dated, as well as some others that could not be dated.

\section{Results}

The results of the analysis of palaeofloods offer new flood values that were not described in historical records and that, due to their high magnitude, are very interesting regarding aspects such us the estimation of return periods of the area, climatic and paleoclimatic implications and the hidromorphologic evolution of the Guadiana River during the last 3000 years. Apart from the new palaeoflood data, this work allows us to give a maximum peak discharge to some of the floods with historical mention but without instrumental data and whose assignment of magnitude is done indirectly by means of data about infrastructure damages, economic losses, etc., all these being quite unreliable as the circumstances of the basin have changed dramatically in the last 500 years and big mistakes could be easily made by using this indirect method.

This work modifies the results of the maximum peak discharge obtained in a previous work (Ortega and Garzón, 2003) for some slackwater deposits by improving the calibration with the gauge data by means of a roughness control and a selection process of the PSI and the use of the flood 

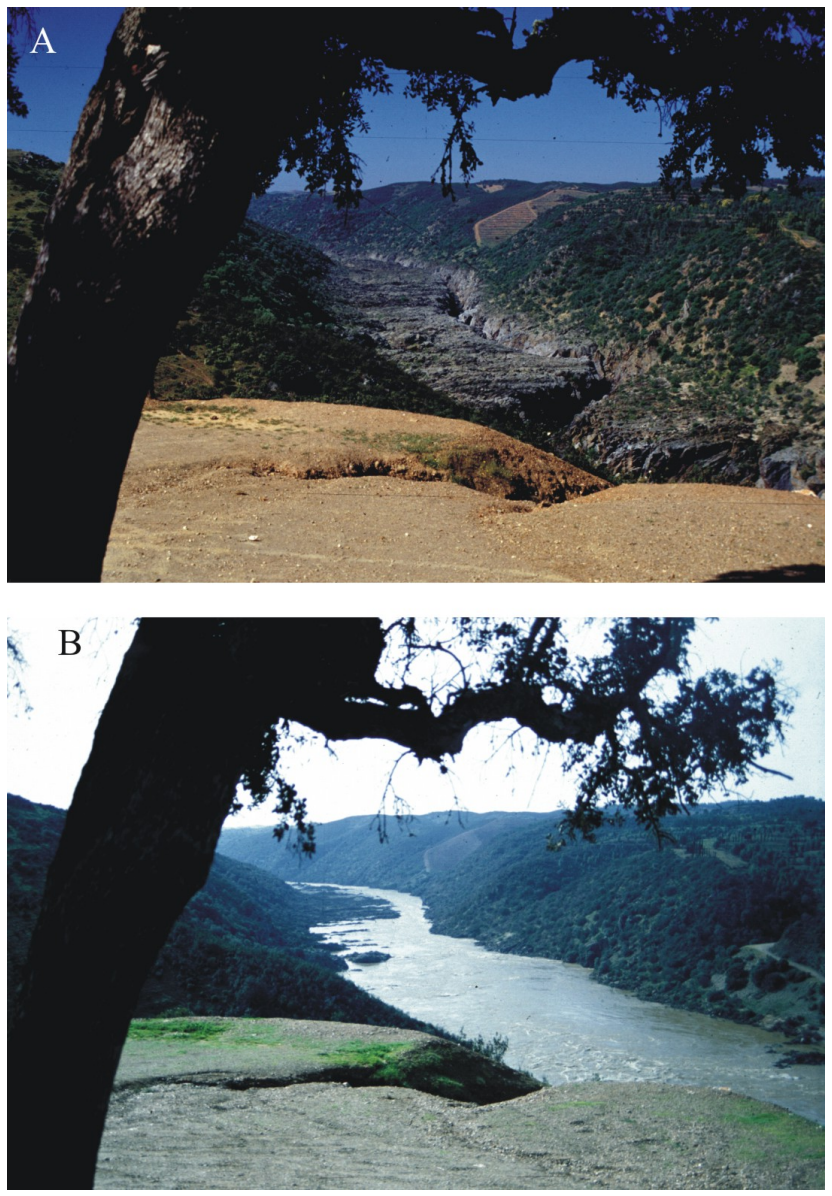

Fig. 3. 1997 Guadiana's river flood used in the hydraulic model calibration. The upper image shows a normal view of the Pulo do Lobo reach, with an open flow inner channel. The lower image shows a view during the 1997's flood with the inner channel and bedrock bench summerged by the waters.

of 1997 as a calibration element with recent systematic data of the gauge station but also with a significant presence of flotsam in all the reach.

The results of the analysis of palaeofloods (Table 1) show that there has been at least one flood larger than that of $1876 \mathrm{AD}\left(10500 \mathrm{~m}^{3} \mathrm{~s}^{-1}\right)$, which is considered one of the largest in the area on the basis of historical discharge records. This flood is estimated to have taken place in $1603 \mathrm{AD}\left(11000 \mathrm{~m}^{3} \mathrm{~s}^{-1}\right)$ and the historical descriptions point to the complete destruction of the Roman Bridge in Badajoz (Ortega, 2007). Other results of maximum peak discharge for palaeofloods which are not mentioned in historical records are $710 \mathrm{cal} \mathrm{BP}\left(10300 \mathrm{~m}^{3} \mathrm{~s}^{-1}\right), 1180 \mathrm{cal} \mathrm{BP}$ $\left(10100 \mathrm{~m}^{3} \mathrm{~s}^{-1}\right)$, which could be probably related to the oldest historical information of the basin, the flood of year $620 \mathrm{AD}$, which destroyed the Visigothic monastery of Cauliana and $3260 \mathrm{cal} \mathrm{BP}\left(10000 \mathrm{~m}^{3} \mathrm{~s}^{-1}\right)$ the oldest flood event

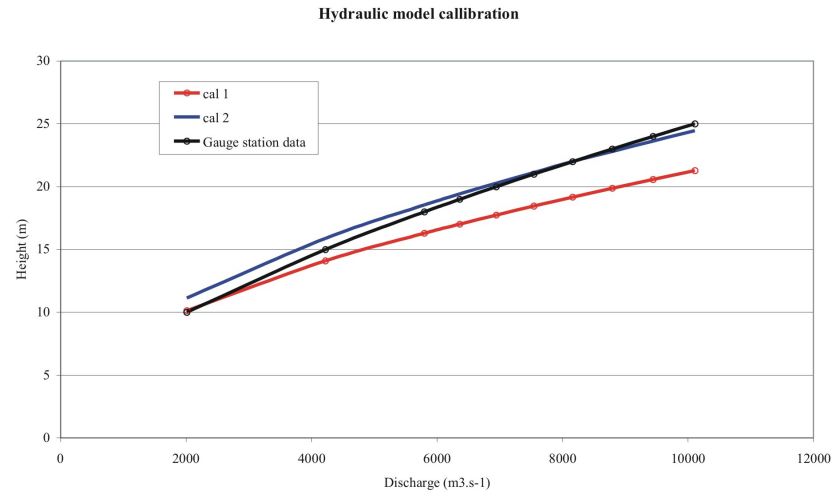

Fig. 4. Calibration model using different Manning's n values. The best fit to high discharge events in the rating curve is Cal 2, who consider high Mannings values. Cal 1 implies a scenario with lower roughness values.

ever found in the basin. Regarding the historical events that have been related to slackwater levels, we find those of $1758 \mathrm{AD}\left(9000 \mathrm{~m}^{3} \mathrm{~s}^{-1}\right), 1947$, already registered in the gauge station $\left(8127 \mathrm{~m}^{3} \mathrm{~s}^{-1}\right), 1545 \mathrm{AD}\left(8000 \mathrm{~m}^{3} \mathrm{~s}^{-1}\right)$. The preservation of deposits of this event might not be complete, for being such an old event and having suffered the flood of 1947, the discharge indicated might be lower to the real one.

As complementary results of the palaeoflood analysis we show, 1) the use of non-systematic data in order to improve the knowledge of magnitude and flood frequency of the basin and 2) the climatic implications of the data of the oldest palaeofloods.

6.1 Use of non-systematic data in flood magnitude and frequency

The results of the analysis of palaeofloods will be used to improve the results of distribution functions at Pulo do Lobo station. The distribution function used is the LN4 (sladetype four parameter LogNormal distribution), for functions with an upper limit, which in this case has been set at a discharge of $8000 \mathrm{~m}^{3} \mathrm{~s}^{-1}$, the minimum result calculated for palaeoflood data. These upper bounded models can be used for PMF estimation (Francés and Botero, 2003). The work of Cunnane (1986) indicates that the interest is in high return period quantiles. The predictive ability of an upper bounded distribution function must be exploited. The programme used for the quantile calculation is AFINS, developed by Francés and Botero (2007).

The evaluation results (Fig. 5) show a clear break in the distribution curve marked by the change from non-systematic to systematic information. A change of tendency appears if we calculate the return periods offered by both curves. Whereas the systematic information indicate that there have been two floods of $8000 \mathrm{~m}^{3} \mathrm{~s}^{-1}$ in a 52 year record (meaning an approximate return period of 29 years), the palaeoflood 

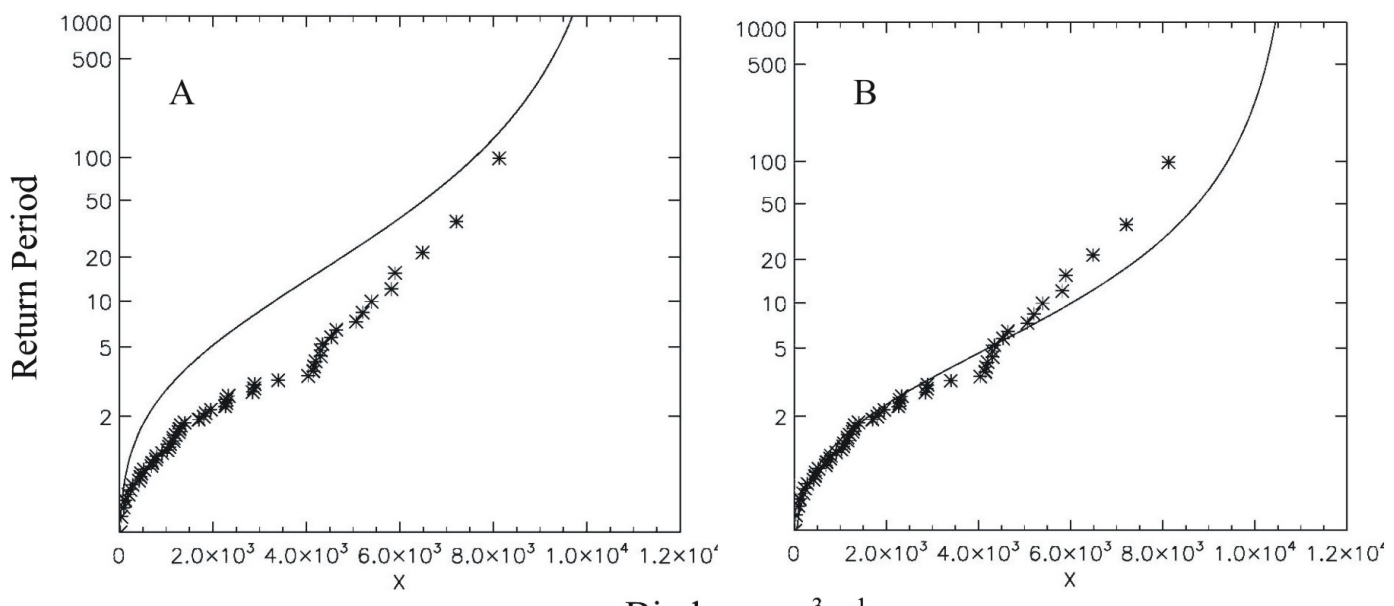

Discharge $\mathrm{m}^{3} . \mathrm{s}^{-1}$
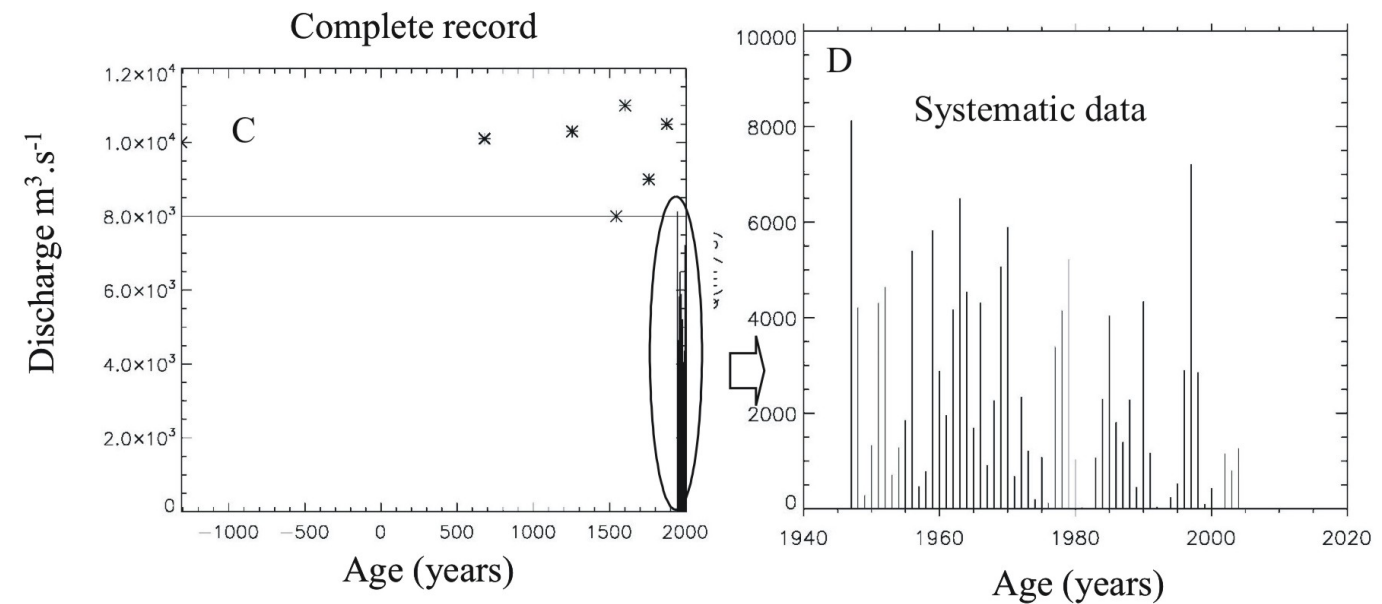

Fig. 5. Graphic representation of the curve described by the return periods at Pulo do Lobo station (27L/01) by the distribution function LN4 using systematic (A) and non-systematic information (B). (C) diagram represents a whole record using palaeoflood data and gauge station data. (D) diagram represents a detail of the systematic information obtained from the gauge station at Pulo do Lobo.

record shows 7 floods in 3.256 years ( 465 years of return period). This change of slope could be due to several reasons: 1) the systematic information does not represent the real behaviour of the basin, 2) there are climatic or hydrologic changes that mark differences between the old nonsystematic information and the recent one, and 3) not all the existing palaeoflood events have been registered and therefore the record is not representative. All these points will be discussed later in the final conclusions.

\subsection{Climatic influence in high magnitude floods}

The dating of old flood events may be useful to relate climate variations and floods. In former studies we have found not only a relation of the flood sequence with NAO oscillations (Ortega and Garzón, 2004), but also a possible relation to a cycle change. In this paper, we have try to use our improved record of palaeoflood events for the lower Guadiana River basin to compare the flood moments with the cold and warm pulses determined for Europe by Chaline (1985). The results (Fig. 6) show that high magnitude floods in the basin coincide with moments of cold pulses not only for the oldest palaeoflood events that we have found ( $3260 \pm 40 \mathrm{BP}$, $1180 \pm 40 \mathrm{BP}$ y $710 \pm 40 \mathrm{BP}$ calibrated ages) but as well as in the most recent events assigned to certain historical floods $(1545,1603,1758,1823$ and $1876 \mathrm{AD})$. We have not found yet, however, any records of floods in the basin for some of the other cold pulses (like the ones around $4500 \mathrm{BP}, 2500 \mathrm{BP}$ and $500 \mathrm{AD}$ ). On the opposite, high magnitude flood events never seem to match with warm pulses.

Some high magnitude events seem to be related to moments of change between pulses, like the ones of $1876 \mathrm{AD}$, $1180 \pm 40 \mathrm{cal}$ BP or $710 \pm 40 \mathrm{cal}$ BP floods, all of them within a transition from cold to warm pulses. 
Thorndycraft and Benito (2006) point out seven periods within the Holocene where a concentration of flood episodes occurs. This concentration of deposits is likely to imply a climatic variability (cold or warm phases). Among the most recent episodes that they define (3880-3085 cal BP and $1300-0$ cal BP), we can situate the three older records that we obtained in the lower Guadiana basin. We have found no records in the basin to floods during the Warm Medieval Period (MWP) in opposition to that obtained on their work but we found several during the Little Ice Age Period (LIA), being a period of high magnitude events in all Europe (e.g. Grove, 2001; Macklin and Lewis, 2003; Macklin et al., 2006). In this period (14-19th centuries) we find at least nine high magnitude events (attributed to the 1545, 1596, 1603, $1758,1766,1796,1823,1859$ and 1876 AD historical floods) and associated to a cold period associated to an increase of fluvial geomorphic activity.

\section{Discussion}

Thanks to the use of SWD we interpreted three ancient high magnitude floods that occurred in the basin $(3160 \pm 40$, $1180 \pm 40$ and $710 \pm 40 \mathrm{cal} \mathrm{BP}$ ). Furthermore, we have been able to assign values to other historical floods whose magnitude and peak discharge were unknown The employed methodology allowed us to improve and complete notoriously the knowledge of the basin floods and it also brings significant implications about the quantile calculations, as the distribution functions change considerably by introducing non-systematic information. In relation with these changes, we cannot choose among the three factors ("luck or bad luck" in systematic record, change in climatic patterns and palaeoflood record continuity) as the possible reasons affecting the change of behaviour of the Guadiana River floods in Pulo do Lobo. (1) The "luck" factor at the time of gathering systematic information is no subject of study, though starting the systematic series in 1947, where the highest magnitude flood was registered in the station, definitely interferes with the final result (2 events in 52 years meaning an approximate return period of 29 years, but if the 1947 had not been recorded the return period increases to 52 years). With no doubt the distribution function would have been quite different without the 1947 flood, which in fact represents one of the largest floods in the Iberian Peninsula for the 20th century. With regards to the (2) factor causing the change, palaeoflood data confirm that before XX century, floods are better related to cold periods and especially with moments of change. The 1947 flood, however, settled in a warm period according to Chaline (1987) breaks this tendency. Unfortunately, there is not enough perspective yet to see whether the rest of systematic flood record confirms increase in high magnitude floods in this apparent last warm period follows the same tendency.

The occurrence of high magnitude floods in the lower Guadiana River basin into the cold climate periods coincide with

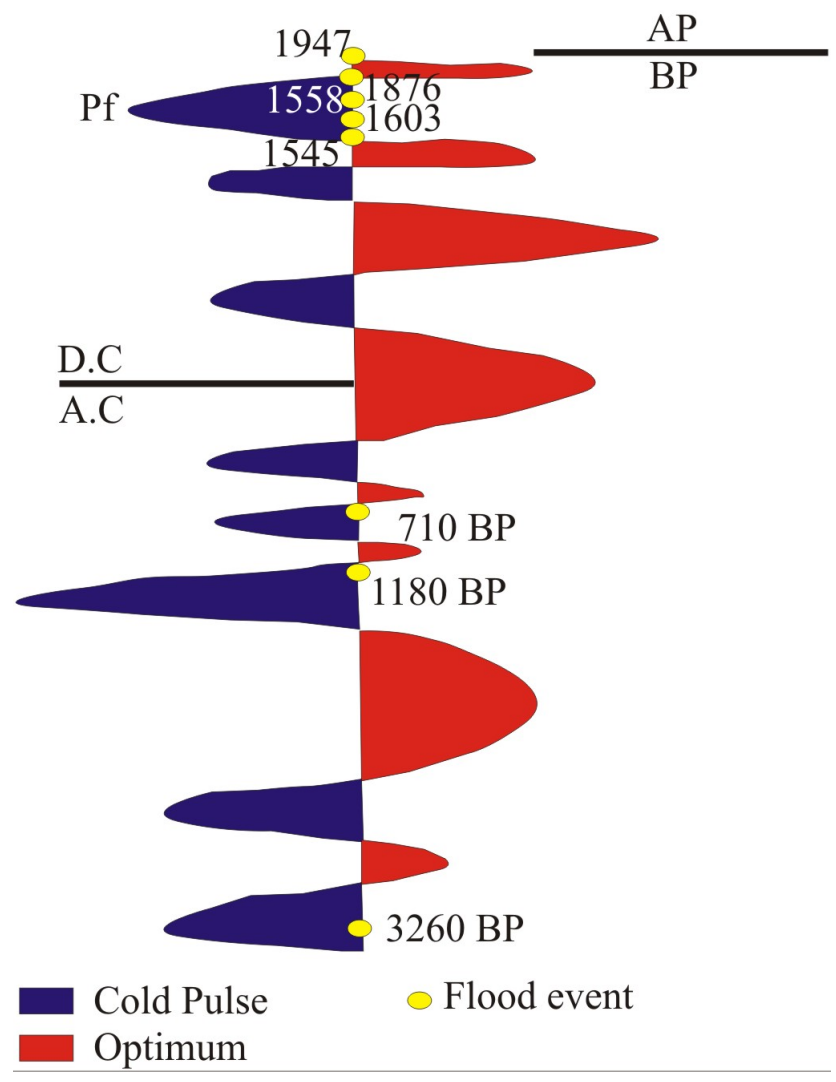

Fig. 6. Flood events in the Guadiana River in Pulo do Lobo reach. In blue colour cold pulses who contain the majority of high magnitude events. In red colour warm pulses in which only one flood occur (1947 AD). Pf: Fernau cold pulse (Modified from Chaline, 1987).

some results from Thorndycraft and Benito (2006) in Spain. The lower basin in Portugal has the same general behaviour that the upper one, and similar to any other basins in the Iberian Peninsula. It is also significant and a goal of this study, the special placement of the high floods in transitions from cold to warm periods. Further studies are necessary to improve these results and extend and correlate this trends according to hydroclimatic patterns like changes in NAO index. Ortega and Garzón (2004) have already established a good fit between negative phases in NAO index and historical Guadiana winter floods. Such events, from December to early March cause the majority of high magnitude floods. A medium-high magnitude flood, like the recent $1947 \mathrm{AD}$ one, may indicate, however, a change in hydroclimatic patterns, and further research is needed to assess this statement based only in one event.

In the same sense, Benito et al. (2008) also noted that the successive passage of Atlantic cold fronts over the Iberian Peninsula in winter months caused flooding in large Atlantic (Iberian) river catchments. In terms of the palaeoflood 
records, they suggest periods with high flood frequency that should be associated with a prevailing negative winter NAO mode.

The palaeoflood data may be used for a better understanding of potential impacts of future climate change (Gregory et al., 2006) at least over the last 3000 years, when present-day atmospheric circulation was probably in existence (Knox, 1983).

Finally, the last point is clear. (3) Radiocarbon dated slackwater deposits might not represent the integral record, and according to it, palaeoflood based frequency studies may not be entirely realistic. The non-systematic (palaeoflood record) is incomplete and it is difficult to find a good range of events, especially of medium and low magnitude, which are eroded by subsequent events. In fact a recent example of it was founded in the last flood event, the mean magnitude 1997 one, whose SWD have been already partially eroded after 10 years. Anyway, the high magnitude paleoflood represent a usefull tool to improve distribution function curves and in PMF studies for high return period design works.

Acknowledgements. The authors thank F. Francés for his help with the distribution function data. P. Muñoz and J. Garrote also provided field support during earlier stages of the work. We would also like to thank Victor R. Baker (University of Arizona) and Juergen Herget (University of Bonn) for their comments, which helped improve the original manuscript. We are also grateful to G. Pinto (Geodynamics Dept.) for his laboratory analysis of the SWD. This work was funded by CICYT project No. HID96-1318/96 of the Spanish Ministry of Education and Science.

Edited by: T. Glade

Reviewed by: V. Baker and J. Herget

\section{References}

Baker, V. R.: Paleoflood hydrology and extraordinary flood events, J. Hydrol., 96, 79-99, 1987.

Baker, V. R.: Magnitude and frequency of paleofloods, in: Floods: Hydrological, sedimentological and geomorphological implications, John Wiley, New York, 171-183, 1989.

Baker, V. R., Patton, P. C., and Kochel, R. C. (Eds.): Flood geomorphology, Wiley, USA, 503 pp., 1988.

Benito, G., Machado, M. J., and Perez Gonzalez A.: Climate change and flood sensivity in Spain, in: Global Continental Changes: the context of palaeohidrology, Geological Society Special publication, 115, 85-98, 1996.

Benito, G., Machado, M. J., Pérez-González, A., and Sopeña, A.: Palaeoflood hydrology of the Tagus river, Central Spain, in: Palaeohydrology and environmental change, John Wiley \& Sons, Chichester, 327-333, 1998.

Benito, G., Sanchez-Moya, Y., and Sopeña, A.: Sedimentology of high stage flood deposits of the Tagus river, Central Spain, Sediment. Geol., 157, 107-132, 2003a.

Benito, G., Díez, A., and Fernández de Villalta, M.: Magnitude and frequency of flooding in the Tagus basin (Central Spain) over the last millennium, Climatic Change, 58, 171-192, $2003 \mathrm{~b}$.
Benito, G. and Thorndycraft, V. R. (Eds.): Systematic, Palaeoflood and Historical Data for the Improvement of Flood Risk estimation, Methodological Guidelines, CSIC, Madrid, 115 pp., 2004.

Benito, G., Thorndycraft, V. R., Rico, M., Sánchez-Moya, Y., and Sopeña, A.: Palaeoflood and floodplain records from Spain: Evidence for long-term climate variability and environmental changes, Geomorphology, 101, 68-77, 2008.

Chaline, J.: Histoire de l'homme et des climats au Quaternaire, Doin, Paris, 366 pp., 1985.

Costa, J. E.: Hydraulics and basin morphometry of the largest flash floods in the conterminous United States, J. Hydrol., 93, 313338, 1987.

Cunnane, C.: Review of statistical models for flood estimation, in: Hydrologic Frequency Modeling, edited by: Singh, V. D., Hydrologic Frequency Modeling. Int. Simp. On Flood Frequency and Risk Analysis, Louisiana State University, Baton Rouge, 4995, 1986.

Ely, L. and Baker, V. R.: Reconstructing paleoflood hydrology with slackwater deposits: Verde river, Arizona, Phys. Geogr., 5(2), 103-126, 1985.

Ely, L., Webb, R., and Enzel, Y.: Accuracy of post-bomb ${ }^{137} \mathrm{Cs}$ and ${ }^{14} \mathrm{C}$ in dating fluvial deposits, Quat. Res., 38, 196-204, 1992.

Ely, L., Enzel, Y., Baker, V. R., and Cayan, D. R.: A 5000-year record of extreme floods and climate change in the southwestern United States, Science, 262, 410-412, 1993.

Enzel, Y., Ely, L. L., Martinez-Goytre, J., and Vivian, R. G.: Paleoflood and dam failure flood in the Virgin River, Utah and Arizona, J. Hydrol., 153, 291-315, 1994.

Ferrer, M., González de Vallejo, L., García, J. C., and Rodríguez, J. A.: Pérdidas por terremotos e inundaciones en España durante el periodo 1987-2001 y su estimación para los próximos 30 años (2004-2033), CCS, Madrid, 126 pp., 2004.

Francés, F. and Botero, A.: Probable maximum flood estimation using systematic and non-systematic information, in: Palaeofloods, historical data and climatic variability: applications in flood risk assessment, CSIC, Madrid, 223-230, 2003.

Francés, F.: Flood frequency analysis using systematic and nonsystematic information, in: Systematic, Palaeoflood and Historical Data for the Improvement of Flood Risk Estimation, Methodological Guidelines, CSIC, Madrid, 55-71, 2004.

Francés, F. and Botero, A.: Flood Frequency Analysis for Extreme Events, in: Advances in Urban Flood Management, Taylor \& Francis, Balkema, 123-138, 2007.

Gregory, K. J., Benito, G., Dikau, R., Golosov, V., Jones, A. J. J., Macklin, M. G., Parsons, A. J., Passmore, D. G., Poesen, J., Starkel, L., and Walling, D. E.: Past hydrological events related to understanding global change: an ICSU research project, Catena, 66, 2-13, 2006.

Grove, A. T.: The Little Ice Age and its geomorphological consequences in Mediterranean Europe, Climatic Change, 28, 121136, 2001.

Hoggan, D. H.: Computer assisted floodplain, Hydrology and Hydraulics, Mc Graw Hill, New York, 518 pp., 1989.

House, P. K. and Peartree, P. A.: A geomorphologic and hydrologic evaluation of an extraordinary flood discharge estimate: Bronco Creek, Arizona, Water Resour. Res., 31(12), 3059-3073, 1995.

Jarret, R. D.: Paleohydrology and its value in analyzing floods and droughts, US Geological Survey Water Supply Paper 2375, 105$116,1989$. 
Knox, J. C.: Responses of river systems to Holocene climates, in: Late-Quaternary Environments of the United States, University of Minnesota Press, Minneapolis, 2, 26-41, 1983.

Kochel, R. C. and Baker, V. R.: Paleoflood analysis using slackwater deposits, in: Flood Geomorphology, Wiley \& Sons, New York, 357-376, 1988.

Macklin, M. G. and Lewin, J.: River sediments, great floods and centennial-scale Holocene climate change, J. Quaternary Sci., 18, 107-120, 2003.

Macklin, M. G., Benito, G., Gregory, K. J., Johnstone, E., Lewin, J., Michczynska, D. J., Soja, R., Starkel, L., and Thorndycraft, V. R.: Past hydrological events reflected in the Holocene fluvial record of Europe, Catena, 66, 145-154, 2006.

O'Connor, J. E. and Webb, R. H.: Hydraulic modeling for paleoflood analysis, in: Flood Geomorphology, Wiley \& Sons, New York, 383-482, 1988.

Ortega, J. A. and Garzón, G.: Palaeohydrology of the Lower Guadiana River Basin, in: Palaeofloods, Historical Data and Climatic Variability: Applications in Flood Risk Assesment, CSIC, Madrid, 33-38, 2003.

Ortega, J. A. and Garzón, G.: Influencia de la oscilación del Atlántico norte en las inundaciones del Río Guadiana, in: Riesgos naturales y antrópicos en Geomorfología, CSIC, Madrid, 117-126, 2004.

Ortega, J. A.: Paleocrecidas, avenidas recientes e hidroclimatología en la cuenca media y baja del río Guadiana, Ph.D. thesis, Universidad Complutense de Madrid, Spain, 535 pp., 2007
Rico, M.: Las paleocrecidas en la cuenca media del río Segre durante el pleistoceno superior-holoceno: registros morfosedimentarios y análisis hidrológico, Ph.D. thesis, Universidad de Zaragoza, Spain, 398 pp., 2004.

Shepard F. P. and Schumm, S. A.: Experimental study of river incision, Geol. Soc. Am. Bull., 85, 257-268, 1974.

Thorndycraft, V. R., Benito, G., Walling, D. E., Sopeña, A., Sanchez-Moya, Y., and Rico, M.: Radiocarbon and caesium-137 dating of slackwater flood deposits of the Llobregat River (NESpain), in: Palaeofloods, Historical Floods and Climatic Variability: Applications in Flood Risk Assessment, CSIC, Madrid, 25-32, 2003.

Thorndycraft, V. R., Benito, G., Rico, M., Sánchez-Moya, Y., Sopeña, A., and Casas, M. A.: A late Holocene palaeoflood record from slackwater deposits of the Llobregat river, N.E. Spain, J. Geol. Soc. India, 64, 549-559, 2004.

Thorndycraft, V. and Benito, G.: The Holocene fluvial chronology of Spain: evidence from a newly compiled radiocarbon database, Quat. Sci. Rev., 25, 223-234, 2006.

Trigo, R. M., Pozo-Vazquez, D., Osborn, T. J, Castro-Diez, Y., Gámis-Fortis, S., and Esteban-Parra, M. J.: North Atlantic Oscillation influence on precipitation, river flow and water resources in the Iberian Peninsula, Int. J. Climatol., 24, 925-944, 2004.

Wohl, E. E.: Bedrock benches and boulder bars: Floods in the Burdekin Gorge of Australia, Geol. Soc. Am. Bull., 104, 770-778, 1992.

Wohl, E. E., Thompson, D., and Miller, A.: Canyons with undullating walls, Geoph. Soc. Am. Bull., 111(7), 949-959, 1999. 